\title{
CORRECTION
}

\section{Author Correction: Mitochondrial DNA synthesis fuels NLRP3 inflammasome}

Rebecca C. Coll ${ }^{1}$, Caroline L. Holley ${ }^{1}$ and Kate Schroder (1)

Cell Research (2018) 28:1202; https://doi.org/10.1038/s41422-018-0112-9

Correction to: Cell Research (2018) 28:1046-1047; https://doi.org/ 10.1038/s41422-018-0093-8; Published online 03 October 2018.
In the initial published version of this article, there was a mistake in the title. The correct title should be "Mitochondrial DNA synthesis fuels NLRP3 activation". This correction does not affect the description of the results or the conclusions of this work. 